\title{
BIOGRAPHIES
}

\section{EMIL TURDEANU - A PERSONALITY OF THE ROMANIAN EXILE}

\author{
Maria Andreia Fanea \\ Biblioteca Centrală Universitară „Carol I” Bucureşti \\ Email: faneaandreea@yahoo.com
}

Biographical Data of Professor Emil Turdeanu

Professor Emil Turdeanu is an important name in Romanian science and abroad. Unfortunately, he did much of his writing in exile. He was a Slavist, a specialist in Slavic texts, particularly in old Romanian literature, but he also wrote political studies about Romania.

He was born in Transylvania, on November 10th, 1911, at Şibot in Alba County. His father, Ilie, was from Turda and his mother, Ana Olteanu, was born near Sălişte. It is her that Emil Turdeanu would speak about with much love and emotion, for she was the one who imbued him with love for his country and people. There were three children. Emilian Turdean, the name written in the Orthodox baptism certificate, was seven years old when the Great Union occurred on December 1st, 1918.

He did his studies at Alba Iulia, Bucharest and then Paris and completed them in Bulgaria, at Sofia, in Belgrade and in Yugoslavia. While attending Nicolae Cartojan's lectures, he realised that he was particularly interested in old Romanian literature, therefore he chose this specialty. In 1943, the future professor Turdeanu married Laetiţia Cartojan, the daughter of his teacher, Nicolae Cartojan. After the establishment of the communist regime, he refused to return to the country and remained in France. His academic career was dedicated to Romania and to the Romanian culture. He took his PhD at the University of Bucharest, the Faculty of Letters, in 1943, and in Paris and was employed at the Sorbonne, as a lecturer of Romanian, by Professor Mario Roques and later by professor Jean Boutière at the National Centre for Scientific Research (CNRS), where, from October 1948 to October 1976, he occupied the po- sition of researcher, then principal investigator and maître de récherche; a year later he retired. In recognition of the value of his work, Emil Turdeanu was made maître de récherche honoraire. Laetiţia Cartojan, the professor's wife, was appointed lecturer of Romanian at the Sorbonne, as a continuation of his activity. Having withdrawn from his position in Paris, the University of Rome entrusted him with the department of Romanian language and literature until his final retirement, when he returned to his home near Paris.

In 1990, his wife died. This loss caused a decline in Turdeanu's state of mind; as the Professor was also ill, he had to move to a home for the retired teachers and researchers of the University and CNRS. Unfortunately, he could no longer write, as his hand was paralysed. Friends would find news about Professor Turdeanu from his son, who was an architect near Bordeaux.

As one can note in his studies, throughout his life Emil Turdeanu was concerned with Romanian culture and with Romania. Along with other Romanians in exile, he fought against the communist regime in France and in other countries. He played an active part in the Romanian communities in exile and participated in all their actions: he was a member of the community in France.

In Germany he published in Apoziţia journal, while in the USA he was a member of the AmericanRomanian Academy of Arts and Sciences, took part in its annual Congresses and published in Journal ARA, taking a stand, alongside the other members, against the communist regime in the country. He was also a member of the Executive Committee until 2000. In 1993 he was awarded the title of Doc- 
tor Honoris Causa of the University of Bucharest. That winter, he saw Bucharest again. His greatest wish was to revisit his native places in Transylvania, but he could not go due to poor health. In 1995, the Romanian Academy elected him honorary member. However, he was unable to go to Bucharest to attend the ceremony. With the assistance of the Romanian Embassy in Paris and of the UNESCO Romanian ambassador, the ceremony, in which the academician Eugen Simion participated, was held in Paris. A large number of Romanians and French came to celebrate the professor. He was truly moved. Furthermore, in 1997, at the age of 85, Professor Turdeanu was celebrated at Casa Românească in Paris, where his friends spoke about his research and the professor recounted, with much talent and melancholy, some of his memories, which made a great impression on the participants.

He died at the age of 89 at Fresnes, in France, on January 16th, 2001, in Arès commune near Bordeaux.

\section{The scientific activity of Prof. Emil Turdeanu}

After a half of century of exile, long years of almost complete interdiction of his name, because his studies were accessible only at the Academy Library in Room III containing "secret" publications and only with a special signature, Professor Emil Turdeanu is not still sufficiently known in the circle of specialists, although his main works were published in the most famous journals in Europe.

Emil Turdeanu's scientific activity, which debuted in the country with a study published in 1932, evolved mainly in the journal "Cercetări literare" directed by Professor Nicolae Cartojan, a member of the Romanian Academy, in which he published six extensive studies and his doctoral thesis. He also published in other journals, such as "Buletinul Institutului Român din Sofia", which he founded, and "Studii literare", under the supervision of Professor Dumitru Popovici from the University of Cluj.

In 1933, Nicolae Cartojan sent him to Sofia to complete his specialisation in Romanian old literature and culture with Slavonic studies, and in 1935 the Council of the Faculty of Letters recommended him for a scholarship at Şcoala Română in France. In November 1938, the Rector of the University of Paris appointed him lecturer of Romanian language and literature at the Sorbonne, based on the recommendation of professors Mario Roques and Jean Boutière. Moreover, he went, two summers, to Belgrade to gather a rich material regarding the cultural relationships between Romanians and Serbs, which led to the publication of some articles about these cultural relationships.

Based on his training as a Slavist and following a contest for the position of university lecturer which took place in Bucharest, in which he ranked first, Emil Turdeanu was sent by the Romanian State, during the war, as a teacher at the Romanian Institute in Sofia. He was also to occupy the position of lecturer at the University, but unfortunately he was denied the establishment of such position.

In 1942 he defended his doctoral thesis called "Manuscrisele slave din timpul lui Ştefan cel Mare" (which translates as "Slavonic Manuscripts during Stephen the Great"), and in early 1944 he returned to France to resume his position at the Sorbonne, this time as a "chargé de cours". A year later, he presented his diploma thesis from Ecole Pratique des Hautes Etudes, entitled "La litterature bulgare $\mathrm{du}$ XIVe siecle et sa diffusion dans les pays roumains", in which he proved that the opinion according to which the Slavonic literature in the Romanian countries was the result of a massive immigration of south-Danubian Slavic scholars that had taken refuge from the Turkish conquest was not true. The thesis was published in the Collection of studies of the Slavonic Institute in Paris.

In October 1948 he collaborated and worked at the National Centre for Scientific Research of France where he completed his probation, after 28 years, in 1976, as "Maître de recherche honoraire". Afterwards, the Rector of the University of Rome invited him to take over the direction of the department of Romanian language and literature. Following a competition which he won by unanimity of votes, the Italian Ministry of Public Instruction awarded him the title of university professor, which had been denied to him at the Sorbonne because he had not 
done a PhD there as well. In France he was a collaborator of "Revue des Études slaves", in which, for 30 years, he published 15 studies and articles. Also, he published in "Revue de l'Histoire des Religions" and in the periodical "Revue des Études Roumaines", which he founded and whose editor he was for over 20 years, and in "Fiinţa românească", which he supervised together with Virgil Ierunca.

In England, he collaborated at "Slavonic and East European Review" and "Oxford Slavonic Papers". In Germany, he contributed to Sud-Ost Institut din Munchen and "Die Welt der Slaven" from Wiesbaden, in Holland, "Journal for the Studies of Judaism", in Italy to "Rivista di studi bizantini e slavi", where he was part of the editorial board as well, "Studi bizantini e neoclasici" and "Ricerche slavistche". In Greece he published a book which inaugurated the collection of publications of the "Association of Slavists of the University of Thessaloniki".

Last, but not least, in the United States, he published two works, in the "Romanian Studies" journal, directed by his former student from the Sorbonne, Professor Keith Hitchins from Urbana University (Illinois), and was an active member of ARA in Los Angeles. His volume Modern Romania: The Achievement of Romanian Unity appeared under the aegis of the American-Romanian Academy (ARA) and earned him a prize in 1988, alongside other great scholars in exile. In the abovementioned journals one can find Emil Turdeanu's articles over time.

Professor Emil Turdeanu's main scientific interests were old Romanian literature, apocryphal religious literature and Romanian and South-eastern European literature. If the first two were regrouped in volumes - a 517-page volume entitled Études de littérature roumaine et d'ecrits slaves et grecs des Principautés roumaines, Brill, Leyda, in 1985, and another one of 497 pages entitled Apocryphes slaves et romains de l'Ancien Testament, also published by E. J. Brill, Leyda, in 1981 - his last scientific concerns have not so far been gathered in a volume; they consist of many studies on aspects of political and cultural history of Romania, as well as chapters from the Romanians' relations with Ragusa, medi- aeval Serbia, Bulgaria, Mount Athos, Russia. They were published in various journals in the country prior to 1944 and abroad, during his exile.

His years in Rome gave him the opportunity to work in libraries there, particularly that of Vatican. It was here that he collected new data for his research on the apocryphal texts of the Old and New Testament, Judeo-Christian texts. Emil Turdeanu is internationally recognized as a specialist of great value.

He published nearly a hundred articles and studies and several books. Most of them appeared naturally abroad. However, several years ago, when the professor turned 85, Editura Enciclopedică printed a first collection titled Oameni şi cărţi de altădată, under the supervision of professor Ştefan Gorovei and Magdalena Szekely.

This volume aims to provide Romanian researchers and experts in old literature with articles published in various journals in the country, in his youth, and abroad, throughout his entire life. In addition to these books and articles, Professor Emil Turdeanu had, in Paris, the great merit to issue Revue des Etudes Roumaines, along with other scholars. The journal is run today by Professor Gorovei, who so far has managed to publish one volume in the country.

Professor Turdeanu's wish was for his library and archive to be brought into the country. Following 1989, he donated his library to "G.Călinescu" Institute of Literary History and Theory in Bucharest. "It was with great financial costs and effort that he, for years on end, mailed parcels of books from his library to Romanian researchers, offering them with much generosity" (Petre Năsturel). A set of 36 letters from 1948-1967, addressed to Grigore Nandriş, were published by Ionel Oprișan at Editura Saeculum in 2000.

In 1995 Editura Minerva published the book Studii şi articole literare, containing articles and studies by Emil Turdeanu and Laetiţia Turdeanu-Cartojan. The issue gathered studies from the country and from abroad, with a preface and complementary notes by Professor Mircea Anghelescu.

In the two journals, Revue des Études Roumaines and Fiinţa românească, most of the scholars in exile published studies and articles taking stands on 
the situation in the country. The two journals were published under the auspices of the Royal Cultural Foundation in Paris.

Emil Turdeanu remains in the gallery of specialists in western science and culture. His followers, teachers and researchers, are still reading his works with devoutness.

\section{References:}

ANGHELESCU, Mircea. Libertatea nu înseamnă să faci orice, interview first published in Literatorul journal, 3, nr. 50 (119), 17-24 decembrie 1993, Bucureşti, p. 6.

ANGHELESCU, Mircea. Postfaţă la Emil Turdeanu; Laetitia Turdeanu-Cartojan. Studii şi articole literare. Bucureşti: Editura Minerva, 1995.

BARBU, Violeta. Emil Turdeanu (10 noiembrie 1911-14 ianuarie 2001). In: Studii şi Materiale de Istorie Medie. Brăila: Editura Istros, Muzeul Brăilei, Vol. 20, 2002, pp. 11-14.

BUCUR, Marin. Contribuţia lui Emil Turdeanu la revistele culturale ale exilului românesc. In: Revista de istorie şi teorie literară, anul 39, Nr.3-4, iuliedecembrie 1991, pp. 235-239.

BUCUR, Marin. Emil Turdeanu (11 noiembrie 1991, Şibot-Hunedoara). In: Istoriografia literară românească de la origini până la G.Călinescu. Bucureşti: Editura Minerva, 1973, pp. 434-437.

CONSTANTINESCU, Emil. PROFESORUL Emil Turdeanu-Doctor Honoris Causa al Universităţii din Bucureşti, cuvântul prof. univ. dr. Emil Constantinescu, rectorul Universităţii din Bucureşti, rostit în şedinţa solemnă a Senatului Universităţii din 22 noiembrie 1993. In: Romanoslavica 31, Bucureşti: Editura Universităţii din Bucureşti, 1994, pp. 137-143.

CONSTANTINESCU, Mihaela. În exil, meditând la destinul culturii româneşti prădate de ruşi. In: Jurnalul literar. An 11, nr. 3-6, feb-martie, 2000, p. 6.
DIALOGURI esenţiale (interviu Nicolae Florescu cu Emil Turdeanu): Cu Emil Turdeanu despre respectul adevărului. In: Jurnalul literar. An 11, nr. 3-6, feb-martie, 2000, p. 1, p. 6 and 30.

MANOLESCU, Florin. Enciclopedia exilului literar românesc 1945-1989. Bucureşti: Editura Compania, 2010.

MAREŞ, Alexandru. Emil Turdeanu (1911-2001). In: Limba română. Anul 60, nr.4, oct-decembrie, 2011, p. 464-467.

MIHĂILĂ, Gheorghe. Emil Turdeanu şi „Revue des Études roumaines”. In: Revista de istorie şi teorie literară, anul 39, Nr.3-4, iulie-decembrie 1991, pp. 223-235.

NĂSTUREL, Petre. Dar de vorbă şi dar de condei. In: Jurnalul literar, serie nouă, An XI, nr.3-6, feb.-martie, 2000, p. 1 (cont. in p. 6).

OIŞTEANU, Andrei. Din nou despre Emil Turdeanu. In: Jurnalul literar nr. 1, 12 noiembrie, nr. 4546, 1990, p. 3 la rubrica Intelectuali din exil.

O RADIOGRAFIE a exilului românesc. Corespondenţă emisă şi primită de Grigore Nandriş (editor şi prefaţator I. Oprişan). Bucureşti: Editura Saeculum I.O., 2000.

Pr. MIHAIL Paul. Contribuţia lui Emil Turdeanu în domeniul literaturii religioase la români. In: Revista de istorie şi teorie literară, anul 39, Nr.3-4, iulie-decembrie 1991, pp. 211-219.

ROMÂNI în ştiinţa şi cultura occidentală. Academia Americano-Română de Ştiinţe şi Arte (Enciclopedie, vol. 13, editor Ion Manea): California: Davis, 1992.

TURDEANU, Emil. Modern Romania. The achievement of National Unity 1914-1920, editor Nicholas Timiras. Los Angeles: ARA, 1988.

ZAMFIRESCU, Dan. Un savant cercetător al literaturii române vechi: Emil Turdeanu. In: Contribuţii la istoria literaturii române vechi, Bucureşti: Editura Ştiinţifică şi Enciclopedică, 1981, pp. 262-271. 